ENTREPRENEURSHIP AND SUSTAINABILITY ISSUES

ISSN 2345-0282 (online) http://jssidoi.org/jesi/

2020 Volume 8 Number 2 (December)

http://doi.org/10.9770/jesi.2020.8.2(28)

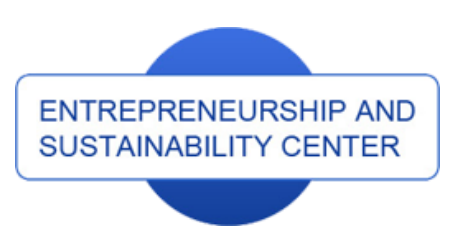

Publisher

http://jssidoi.org/esc/home

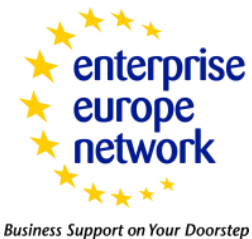

\title{
AN INTEGRATIVE STUDY OF THE IMPLICATIONS OF THE RISE OF COWORKING SPACES
} IN SMART CITIES

\author{
Fang Zhao ${ }^{1}$, Catherine Prentice ${ }^{2}$, Joseph Wallis ${ }^{3}$, Arvind Patel ${ }^{4}$, Marie-France Waxin ${ }^{5}$ \\ ${ }^{I}$ Staffordshire University, Stoke-on-Trent, ST4 2DF, United Kingdom \\ ${ }^{2}$ Griffith University, Brisbane, Queensland, Australia \\ ${ }^{3}$ American University of Ras Al Khaimah, RAK, United Arab Emirates \\ ${ }^{4}$ The University of the South Pacific, Suva, Fiji \\ ${ }^{5}$ American University of Sharjah, Sharjah, United Arab Emirates \\ E-mails:1fang.zhao@staffs.ac.uk; ${ }^{2}$ cathyjournalarticles@gmail.com; ${ }^{3}$ joseph.wallis@aurak.ac.ae; \\ ${ }^{4}$ Arvind.Patel@usp.ac.fj; ${ }^{5}$ mwaxin@aus.edu
}

Received 16 July 2020; accepted 31 August 2020; published 30 December 2020

\begin{abstract}
Coworking practices have proliferated around the world being embraced not only by remote workers, start-up employees and freelancers but also by larger organizations. Coworking spaces in public libraries, business districts and other urban spaces, herald profound changes for the way workspaces are used in cities. The study takes an integrative approach to investigate the economic and socio-cultural implications of coworking trend for smart cities, their ecosystems and the use of urban public spaces. The study examines these issues by studying motivations and challenges of providers and users of coworking spaces. Thirty coworking spaces in urban areas across Australia were studied and thirty-four semi-structured interviews were conducted with both providers and users of the coworking spaces. The findings suggest that coworking spaces play an important role in building communities and developing social and cultural ties. From urban space and environmental perspectives, coworking spaces are likely to contribute to urban mobility and sustainability. From an urban economic perspective, coworking spaces provide a collaborative environment and often a breeding ground for entrepreneurship. Entrepreneurship is one of the most salient themes in the coworking spaces as found in this study. These findings will inform urban policy makers and help them better understand and tap into the source of civic entrepreneurship derived from coworking spaces.
\end{abstract}

Keywords: coworking spaces; smart cities; ecosystems; entrepreneurship; urban planning; public spaces

Reference to this paper should be made as follows: Zhao, F., Prentice, C., Wallis, J., Patel, A., Waxin, M.-F. 2020. An integrative study of the implications of the rise of coworking spaces in smart cities. Entrepreneurship and Sustainability Issues, 8(2), 467-486. http://doi.org/10.9770/jesi.2020.8.2(28)

JEL Classifications: L26, M10, H83 


\section{ENTREPRENEURSHIP AND SUSTAINABILITY ISSUES}

ISSN 2345-0282 (online) http://jssidoi.org/jesi/

2020 Volume 8 Number 2 (December)

http://doi.org/10.9770/jesi.2020.8.2(28)

Make your research more visible, join the Twitter account of ENTREPRENEURSHIP AND SUSTAINABILITY ISSUES: @Entrepr69728810

\section{Introduction}

Public spaces in urban areas as part of urban planning and urban governance have attracted extensive research interest over the last 20 years from various perspectives (Ravazzoli and Torricelli, 2017). For instance, architects and urban planners are interested in public physical space and people; urban sociologists study the role of public spaces in building social relations; and political scientists look into the use of public space for civil engagement and democracy. From a socio-cultural perspective, public spaces are considered places for social interaction, playing a central role in the creation of inclusive communities (Costamagna et al., 2019). Coworking spaces have been defined as 'shared workspaces utilized by different sorts of knowledge professionals, mostly freelancers, working in various degrees of specialization in the vast domain of the knowledge industry' (Gandini, 2015, p. 194). They can be referred to as a type of public space since they are 'publicly accessible places where people go for group or individual activities' (Carr et al., 1992, p. 50).

Although the concept of contemporary coworking originated in 2005 in San Francisco, it is only in the past few years that co-working spaces have become a striking and visible feature of metropolitan (Gandini, 2015; Nathan, 2017). Coworking practices have proliferated around the globe being embraced not only by remote workers, startup employees and freelancers but also by larger organizations. A recent estimation shows that there are 14,411 coworking spaces in the world today with the number predicted to rise to 5.1 million by 2022 (Amador, 2018). Coworking spaces, according to Bounchen et al. (2018), generally have four distinct archetypes: the corporate, the open corporate, the consultancy, and the independent coworking spaces:

- Corporate coworking spaces are created by firms for their employees as a novel avenue for creativity, innovation and intrapreneurship;

- Open corporate coworking spaces are open both to internal and external users to encourage innovation and creativity among internal users and between internal and external users;

- Consultancy coworking spaces are usually created by consulting firms to organize and manage projects, relationships and networks with externals; and

- Independent coworking spaces offer membership to the public. They are mostly located in public libraries, business districts and other urban spaces and are characteristically open for public use.

For the purpose of this study, we refer to coworking spaces as urban public spaces which are aligned with ecosystem initiatives for the development of smart cities. There is a growing body of empirical evidence that some city governments support the growth of coworking spaces through public funding and/or offering public spaces such as city council buildings and public libraries (Mariotti et al. 2017). This reflects the importance of coworking spaces to urban governance and urban planning in those cities. Although co-working spaces have attracted considerable media and property market attentions (e.g. Cheung, 2018), research on co-working spaces is still developing as the trend grows. To the best of our knowledge, limited empirical research has been published to answer the important questions such as: what are (or could be) the economic and socio-cultural implications of co-working trend for smart cities, their ecosystems and the use of urban public space? How should urban policymakers react to the trend?

Smart cities are expected to be a driving force for innovation and entrepreneurship from an economic and business perspective (European Commission, 2019). However, smart cities can transcend the economic and corporate agenda to include social inclusion from cultural and social perspectives. The rise and growth of coworking spaces has brought the possibility of a new model of work in an environment of collaboration, openness and community where innovation and entrepreneurship thrive, and new fabrics of social culture develop. In this regard, an integrative approach is needed to study the rise of the coworking spaces and its implications for smart cities 


\section{ENTREPRENEURSHIP AND SUSTAINABILITY ISSUES}

ISSN 2345-0282 (online) http://jssidoi.org/jesi/ 2020 Volume 8 Number 2 (December)

http://doi.org/10.9770/jesi.2020.8.2(28)

Make your research more visible, join the Twitter account of ENTREPRENEURSHIP AND SUSTAINABILITY ISSUES: @Entrepr69728810

planning and governance. This study seeks to address these important issues through a qualitative study of thirty co-working spaces. The findings of the study could have important implications for the planning of smart cities as well as contributing to the burgeoning literature on smart cities research.

The following section reviews the relevant literature on smart city and coworking space. Research questions are raised from this review. The methodology to address these research questions is then outlined. The findings are then presented, followed by a discussion of its research implications as well as the contributions and limitations of the study and directions for future research before we conclude the paper.

\section{Literature Review}

\section{Smart cities}

The smart city movement started in the 1990s (Letaifa, 2015) and has recently gained momentum in urban governments' planning in many countries at various levels - local, state and national (Albino et al., 2015). Research on smart cities often touches on four areas: the technological aspect (e.g. the technological infrastructure and support network for building smart cities); the socio-cultural aspect (e.g. citizen engagement); the politicalinstitutional aspect (e.g. government support and policies); and the economic-business aspect (e.g. business models and profitability). It is generally agreed that the objective of smart cities is to enhance economic growth and social development through innovations in technology and heightened collaboration (Sarma and Sunny, 2017). However, some research also criticizes the concept of smart cities for its narrow epistemological perspective and its corporate agenda that primarily reflects the interests of multi-national consultancies and technology companies (Marvin et al. 2015; Tompson, 2017).

Research shows that smart cities rely on a smart city ecosystem to survive and thrive. Sarma and Sunny (2017, p.848) define a smart city ecosystem as a set of interconnected actors, such as agents (entrepreneurs), decision makers (e.g. policymakers and bureaucrats), framers (e.g. technology providers, supplier networks, and markets), and constituents (e.g. citizens, investors, and labour). We concur with this definition and argue that ecosystems go far beyond a diverse set of actors and networks. The smart city ecosystems should also include processes and systems, policies and governance that support smart city initiatives and development. Research indicates that a paradigm shift towards a more dynamic and open architecture is taking place in smart city governance (Mandeli, 2019). Cooperative governance and private and public partnerships are replacing traditional silo-based governance approaches. Citizens' involvement and community engagement in smart city development becomes an important aspect of discourse reflected in policy statements (European Commission, 2019; Trencher, 2019) and smart city strategies, and an area viewed as critical in smart city initiatives and research agendas (UNESCO 2019; Marek et al., 2017). Smart cities are about smart people. While smart technologies play a key role in making cities connected and digitalized, it is people who drive, create and take up technologies. Therefore, the success of smart cities lies in the creation and development of their people. Human and social capital are considered as the key pillars of the ecosystems, which smart city strategies seek to develop and nurture. Angelidou (2015) recommends that dedicated areas are needed within smart cites, where people can collaborate and engage in innovative activities that may lead to the development of human and social capital. Such areas are referred to coworking spaces. 
ENTREPRENEURSHIP AND SUSTAINABILITY ISSUES

ISSN 2345-0282 (online) http://jssidoi.org/jesi/

2020 Volume 8 Number 2 (December)

http://doi.org/10.9770/jesi.2020.8.2(28)

Make your research more visible, join the Twitter account of ENTREPRENEURSHIP AND SUSTAINABILITY ISSUES: @Entrepr69728810

\section{Coworking space}

Coworking practice has become a new model of workplaces in today's collaborative and sharing economy (Botsman and Rogers, 2011; Avdikos and Merkel, 2020). Many start-ups and some larger companies such as Woolworths, Accenture and LG Electronics have embraced the coworking space concept (Office Hub, 2018) because of the merits of collaborative working environment and the cost-effectiveness in terms of flexible leasing terms (Zhou, 2019). Public libraries are a popular form of coworking space. According to the president of American Library Association, many libraries in the US are being re-invented into modern community spaces, offering free coworking spaces for growing numbers of entrepreneurs, for whom they are better alternatives to coffee shops and a much cheaper option than hiring a desk in commercial coworking spaces like WeWork (Krueger, 2019).

Research on coworking spaces from both the perspectives of academic and practitioners has flourished over the past decade (Gandini, 2015). Based on a relational constructionist lens, Garrett et al. (2017) explore how members of a coworking space work together to co-construct and sustain a sense of community through their daily interactions. The study found that the sense of community was achieved through three overlapping interactions endorsing, encountering, and engaging among members working in the coworking spaces.

Coworking spaces have also the benefits of work flexibility, serendipitous encounters with like-minded people, idea generation and sharing, business networking, and a relief from loneliness of working from home (e.g. King. 2017; Garrett et al., 2017). Mariotti et al's (2017) study investigates the location patterns of coworking spaces through a case study of Milan, Italy and assesses their effects on the urban context. The findings suggest that the participation of workers in coworking spaces contributes to local community initiatives, urban revitalization trends, and micro-scale physical transformations. The study of Bueno et al (2017) suggests that coworking spaces are likely to increase productivity through offering collaborative networks and a dynamic ecosystem to foster innovation.

However, critiques of coworking spaces question a somewhat self-proclaimed and often overenthusiastic evaluation of positive outcomes from coworking spaces (Gandini and Cossu, 2019). From an economic and business perspective, the study of Moriset (2014) points out the risks of possible 'coworking bubbles' driven by the profitability concerns. The study of Bounchen et al. (2018) analyses the cooperative tensions in value creation and appropriation in various types of coworking spaces.

The mixed reactions to the concept and practices of coworking spaces warrant better understanding of the trend. Moreover, what roles do coworking spaces play in smart city ecosystem in general and in entrepreneurship in particular. These questions remain largely underexplored in the current literature of either smart cities or entrepreneurship. As pointed out by the study of Mariotti et al (2017), empirical evidence and critical analysis are limited about the role of coworking spaces in smart cities, their ecosystems and the use of urban public space. We seek to address the gap in an integrative way through investigating the actual and potential economic (in the form of entrepreneurship) and social-cultural impacts of coworking spaces on urban planning and their residents. 
ENTREPRENEURSHIP AND SUSTAINABILITY ISSUES

ISSN 2345-0282 (online) http://jssidoi.org/jesi/

2020 Volume 8 Number 2 (December)

http://doi.org/10.9770/jesi.2020.8.2(28)

Make your research more visible, join the Twitter account of ENTREPRENEURSHIP AND SUSTAINABILITY ISSUES: @Entrepr69728810

\section{Linking coworking spaces to smart city ecosystems}

Over the past decade, research on smart cities has grown exponentially and expanded to multidisciplinary fields, integrating a range of perspectives (Kummitha and Crutzen, 2017; Trencher, 2019). There has been over 200 percent increase in publication volume on smart cities since 2009 (Ojo et al. 2015). The extensive review of the literature on smart cities conducted by Meijer and Bolivar (2016) reveal three common foci that are dominant in extant smart city research, namely, technological focus, human resource focus and governance focus. An international comparative study found that from a leadership perspective, smart cities can be seen as digital government, a digital driver for economic growth, an open platform for digital socio-political innovation, and an open platform for the digital economy (Sancino and Hudson, 2020). For the purpose of this study, we take an integrative approach to the concept of smart cities and view and discuss it from economic, political, social and cultural perspectives.

From an integrative perspective, smart cities are built on a robust ecosystem which should include an innovation environment that nurtures and supports smart cities, including smart people, leadership, strategies and policies, human and social capital, an integrated IT system and a collaborative and open culture (Appio et al, 2019). For example, smart city programs are designed to provide open channels to engage citizens and stakeholders and solicit inputs on the viability of smart city solutions and services in real life contexts (Meijer and Bolívar, 2016). The collaboration among the cities' residents, businesses and public sector is seen as a source of new and effective knowledge production and as a precursor for the development of open knowledge and innovation ecosystems. The smart cities ecosystem is not simply about technology but about culture, people, strategy and governance (Mora et al., 2019).

In this study we seek to understand more about what role coworking spaces play in the context of smart city ecosystems, how they work, the purposes and motivations of running and using coworking spaces, the perceived and realized outcomes of the coworking spaces and the key issues and challenges facing both the supply and demand sides. Hence, this study addresses the following research questions:

- What drives engagement with coworking places?

- What are the issues and challenges of coworking places?

\section{Methods}

To answer the research questions, we followed a qualitative design, arguing that a qualitative methodology allowed us to develop an in-depth understanding of the experiences of both users and providers of the coworking spaces studied and the context in greater detail (Yin, 2011). In line with the qualitative design, we employed semistructured interview method, which provided consistency of questioning across interviews while having the flexibility to explore areas of interest in greater depth.

\section{Sample}

We selected 30 coworking spaces in urban areas across Australia, namely, Perth, Sydney, Melbourne, Brisbane, Adelaide, Hobart, Darwin and Canberra to cover all the major cities in Australia. The selection of Australia for the case study was mainly for three reasons: (1) Australia has been one of the leading countries in smart city transformation (KPMG, 2019); (2) Australia embraces a strong growth in coworking spaces (Cheung, 2018), with coworking spaces having grown by 297 to 309 per cent between 2013 and 2017, and the recent forecast estimates 
ENTREPRENEURSHIP AND SUSTAINABILITY ISSUES

ISSN 2345-0282 (online) http://jssidoi.org/jesi/

2020 Volume 8 Number 2 (December)

http://doi.org/10.9770/jesi.2020.8.2(28)

Make your research more visible, join the Twitter account of ENTREPRENEURSHIP AND SUSTAINABILITY ISSUES: @Entrepr69728810

a tripling in coworking spaces by 2030 (Cheung, 2018); and (3) leading researchers have been intensively involved in smart city projects in Australia.

The key criteria for the selection of coworking spaces included: a wide range of urban locations, a minimum of one-year operation of coworking spaces to see some outcomes, and a mix of private and public ownerships. Another important selection criterion was that the coworking space must be open to the public as this study has been intended to inform evidence-based policies and strategies concerning the public use of urban spaces.

\section{Data collection procedure}

Primary and secondary data for this study was collected during a 6-month period between October 2017 and April 2018, mainly from three sources: (1) extensive research on the websites of every coworking space studied; (2) semi-structured interviews with both coworking spaces providers (owners and/or operators) and users; and (3) site visits to some coworking spaces in Perth. In addition, some of our team members spent several days working in some of the coworking spaces to get first-hand experience.

As described in the previous section, a total of thirty-four semi-structured interviews were conducted with both providers (10) and users (24) of the thirty coworking spaces studied between October 2017 and April 2018. The interviews were conducted either face-to-face or via Skype with the participants in the coworking spaces they were associated with. The interviews took between half an hour and one and a half hours, with the average being close to one hour. All the interviews were tape-recorded and transcribed for analysis. The primary objectives of the interviews were to find out the actual and potential impacts of coworking spaces on users and the challenges and issues the coworking spaces had been facing. From the findings we sought to answer research questions about the roles of coworking spaces in innovation ecosystems of smart cities in economic and socio-cultural terms as well as their implications for future urban planning and governance. Therefore, our interview questions centred around:

- Motivations for providers and users

- Key challenges for providers and users

To ensure a robust and fair representation of stakeholders, we selected participants purposively based on their involvement in coworking spaces, their job type, managerial position, and industry/business sectors. Contact details and some of the demographic information about the participants were found mainly on the company websites of coworking spaces and through contacts during our site visits. After approaching 45 prospective participants by email and telephone, and in person, 34 of them agreed to be interviewed. 
ENTREPRENEURSHIP AND SUSTAINABILITY ISSUES

ISSN 2345-0282 (online) http://jssidoi.org/jesi/ 2020 Volume 8 Number 2 (December)

http://doi.org/10.9770/jesi.2020.8.2(28)

Make your research more visible, join the Twitter account of ENTREPRENEURSHIP AND SUSTAINABILITY ISSUES: @Entrepr69728810

Table 1. Summary of demographics of participants in the interviews $(\mathrm{N}=34)$

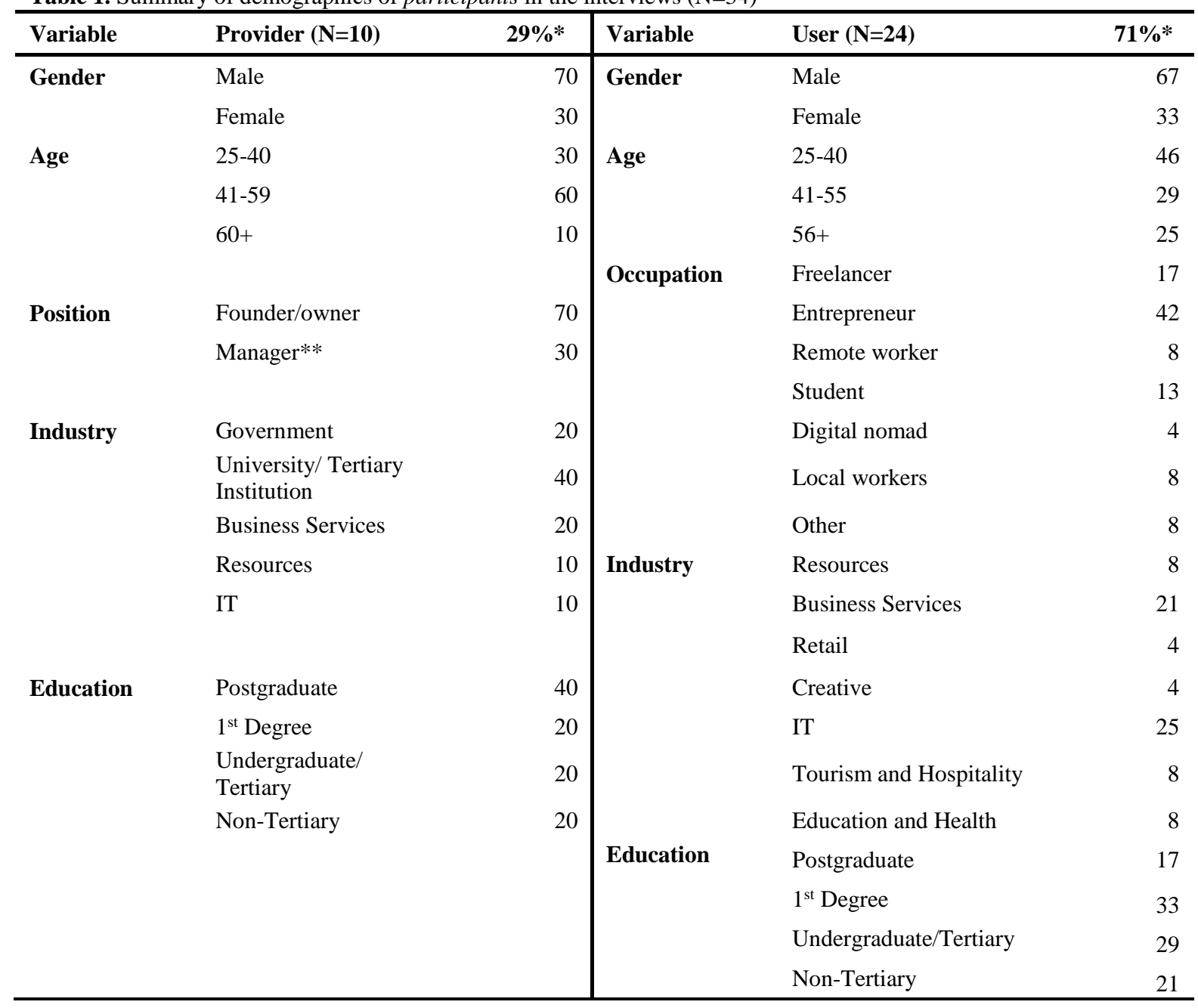

Note: * Figures are percentages of demographics. **Manager category does not include owner or founder.

Table 1 presents a summary of the demographics of the participants in our interviews. We interviewed two groups: 10 providers and 24 users in order to get a comprehensive view of coworking spaces studied. In terms of the gender of the participants, the majority among both providers and users are male. In terms of age group, most of the providers we interviewed aged between 41 and 59. By contrast, the users were youth, millennials, middleaged, and retirees, with a majority aged between 25 and 40. Most of the providers (70\%) were funders and owners with a range of industry backgrounds. We found that users' backgrounds were more diverse, covering various industries and professions. Among the users, the largest group (42\%) were entrepreneurs, followed by selfemployed freelancers (17\%) who did not see themselves as either entrepreneurs or students (13\%). Among the participants, a small number of remote workers were employed by non-local companies. The rest were local workers - employees of local companies, and digital nomads from overseas. The 'other' category included retirees and local residents who were not employed at the time of interview. Overall, the users interviewed corresponding largely with the member profiles of the coworking spaces studied. 
ENTREPRENEURSHIP AND SUSTAINABILITY ISSUES

ISSN 2345-0282 (online) http://jssidoi.org/jesi/

2020 Volume 8 Number 2 (December)

http://doi.org/10.9770/jesi.2020.8.2(28)

Make your research more visible, join the Twitter account of ENTREPRENEURSHIP AND SUSTAINABILITY ISSUES: @Entrepr69728810

\section{Data analysis}

We adopted the data analysis process of Miles and Huberman (1994) which involves three concurrent subprocesses: data reduction, data display, and the drawing of conclusions. The data reduction that we conducted included qualitative content analysis of website contents (secondary data) to understand the background of the coworking spaces studied and the primary data of transcripts and notes from interviews. A theme coding system (using theme as a coding unit) was employed in the data reduction process. Accordingly, the large amount of data was coded and categorized into key themes identified through the repeated reviewing and comparing of data (Minichiello et al. 1990). Appendix presents a snapshot of our data display and the key themes from the interviews.

\section{Findings}

\section{Coworking space - location, size, user profiles, ownership and business models}

Table 2 summarizes the key profiles of the 30 coworking spaces we studied. In terms of geographic location, the sample covers every capital city (i.e. 8 in total) in Australia. The majority (64\%) of the coworking spaces were located in the capital city centres and $20 \%$ were located within a $10 \mathrm{~km}$ radius of the capital city centres which were often the business and commercial centres of metropolitan suburbs. The geographic locations of the coworking spaces reflect users' preferences in selecting coworking spaces. As to the age of the coworking spaces studied, they ranged between 1 and 8 years as of 2018, with the majority (67\%) being founded in and after 2015. This finding was consistent with the trend of rapid growth of coworking spaces not only in Australia but also worldwide (Merkel, 2019).

Table 2 Summary of the main profiles of the coworking spaces studied $(\mathrm{N}=30)$

\begin{tabular}{|c|c|c|c|c|c|}
\hline Location & Est. Year & Size & Member profile* & Ownership & $\begin{array}{l}\text { Operating } \\
\text { model }\end{array}$ \\
\hline $\begin{array}{l}\text { City centre = } \\
64 \%\end{array}$ & $\begin{array}{l}2010<= \\
10 \%\end{array}$ & $15<=30 \%$ & Entrepreneur $=40 \%$ & Govt-owned $=10 \%$ & $\begin{array}{l}\text { CWS only }= \\
17 \%\end{array}$ \\
\hline $\begin{array}{l}\text { Within } 10 \mathrm{~km}= \\
20 \%\end{array}$ & $\begin{array}{l}2011-2014= \\
23 \%\end{array}$ & $16-50=23 \%$ & Freelancer $=10 \%$ & $\begin{array}{l}\text { University-owned } \\
=13 \%\end{array}$ & $\begin{array}{l}\text { CWS \& } \\
\text { service }=83 \%\end{array}$ \\
\hline $\begin{array}{l}11 \mathrm{~km}-20 \mathrm{~km} \\
=10 \%\end{array}$ & $2015>=67 \%$ & $51-100=43 \%$ & Remote worker $=10 \%$ & $\mathrm{NGO}-$ owned $=3 \%$ & \\
\hline \multirow[t]{4}{*}{$21 \mathrm{~km}+=6 \%$} & & $100>=3 \%$ & Digital nomad $=5 \%$ & $\begin{array}{l}\text { Privately-owned = } \\
17 \%\end{array}$ & \\
\hline & & & Local employee $=10 \%$ & Joint venture $=57 \%$ & \\
\hline & & & Student $=15 \%$ & & \\
\hline & & & Others $* *=10 \%$ & & \\
\hline
\end{tabular}

Legend: CWS = coworking spaces; Size = number of active members or users

Note: Member profile* is an estimated percentage of the active members' profiles of the 30 coworking spaces studied. Others** category refers to retirees, students, and local residents who do not fall into any of the other categories.

Table 2 shows that the size (i.e. number of the active members) of coworking spaces studied varied with the majority (43\%) of them having more than 50 and up to 100 active members. We found that the size corresponded well with the age of the coworking space, namely, those that were well-established often had more members than those that were relatively more recently set up. 


\section{ENTREPRENEURSHIP AND SUSTAINABILITY ISSUES}

ISSN 2345-0282 (online) http://jssidoi.org/jesi/

2020 Volume 8 Number 2 (December)

http://doi.org/10.9770/jesi.2020.8.2(28)

Make your research more visible, join the Twitter account of ENTREPRENEURSHIP AND SUSTAINABILITY ISSUES: @Entrepr69728810

With respect to user or member profiles, the providers we interviewed were diverse. The majority (40\%) were entrepreneurs but there were also freelancers, remote and local workers, students, retirees, digital nomads and local residents. In terms of ownership, most (57\%) were joint ventures, that is, partnerships between city councils, universities, established companies and/or start-ups and philanthropists. Thirteen were owned and managed by public universities and other tertiary institutions, ten percent were funded entirely by governments such as those coworking spaces in city and state libraries and only three percent were owned by NGOs. The remaining (seventeen percent) were privately owned and operated.

As far as business and operating models were concerned, all were membership-based although fee structures varied, ranging from a nominal fee or no fee to hundreds of dollars per month, depending on the type of membership and ownership. Seventeen percent of the coworking spaces we studied offered office facilities only with no or minimal services. The overwhelmingly majority $(83 \%)$ of the coworking spaces offered both coworking spaces and membership services. These typically included networking events, mentoring and businessrelated training, business mailing address, parking, locker and shower facilities.

We found that some coworking spaces were bundled with other services such as a coffee shop, a meditation room, and a gym. It was interesting to find that nearly 30 percent of the privately-owned coworking spaces that we studied were owned and managed by female entrepreneurs. Some of them were open to women only, offering women-centric services such as child-care and salon services. Three of the coworking spaces were hotel and hostel operators which offered their guests and the general public their coworking facilities. The hostel coworking spaces were particularly appealing to international backpackers and digital nomads. Most recently, some of the coworking spaces started to offer a virtual membership option with a much lower fee to attract those living in regional and remote areas. This option provided members with access to the online coworking community and the events and activities provided by the coworking spaces.

\section{Motivations, objectives, and outcomes - Provider's perspective}

\section{Community building and entrepreneurship}

In terms of the motivations and objectives of establishing and running coworking spaces, the most striking themes from a provider's perspective are community building and entrepreneurship (see Appendix for detail). We found that the providers we interviewed shared a common agenda - creating a coworking community for members to interact with each other, creating and sharing ideas, and facilitating innovation through collaboration. One of the founders of coworking spaces told us:

The objective was to build an entrepreneur eco-system and seek to bring 20,000 entrepreneurs by 2021 into a membership community with 1,000 members.

Another female owner and operator of a coworking space had one ultimate goal, that is, helping women start and build a successful business and start-up by providing a one-stop shop.

When asked about the level of success and outcomes of coworking spaces, two of the founders/owners made the following comments:

At our level, it is more about playing a community role than an actual money-making business, it is more about providing these start-ups with what they need and hopefully see them outgrow the space like a few did. 


\section{ENTREPRENEURSHIP AND SUSTAINABILITY ISSUES}

ISSN 2345-0282 (online) http://jssidoi.org/jesi/

2020 Volume 8 Number 2 (December)

http://doi.org/10.9770/jesi.2020.8.2(28)

Make your research more visible, join the Twitter account of ENTREPRENEURSHIP AND SUSTAINABILITY ISSUES: @Entrepr69728810

After nearly three years' operation, our coworking spaces have helped 11 of our members set up their own businesses and 6 of them have broken even and 1 of them is very successful. We are very pleased with the results so far.

The proceeding comments reflected the different views and motivations of providers in running coworking spaces. However, they shared a common goal of incubating and nurturing entrepreneurs through their coworking spaces.

Interestingly, for university coworking spaces, some of the participants suggested that bringing entrepreneurs and start-up workers to campuses to co-work with students and staff helped with experiential learning and idea generation and development, thus enriching students' learning experience. In some cases, we found in our interviews that students described how their social skills had been developed through the coworking spaces. University coworking spaces were also seen as an innovation hub for university entrepreneurship and research commercialisation, providing students and researchers with access to industry and insights from entrepreneurs, investors and commercialisation experts.

\section{Motivations, objectives, and outcomes - User's perspective}

\section{Social interaction}

As far as coworking space users or members were concerned, we found that people joined coworking spaces for different purposes and with different expectations. The most common reason cited by users was the social interaction among members. However, the social interaction led to different outcomes due to the different motivations of users. For some, the social interaction helped the exploration and sharing of ideas as well as developing new business and professional networks and providing needed opportunities and mentoring advice.

'We've been able to leverage the other people's networks since we joined the coworking space,' said one of the users.

Prior research suggests that informal exchange and cooperation in the form of horizontal interaction with others is likely to lead to knowledge transfer because of geographical, social or cognitive proximity (Boschma, 2005). We found that the eventful aspect of coworking spaces played a key role in members' horizontal interactions and networking. For others, the social interaction helped ease the social isolation and loneliness experienced from working alone. For the remote workers we interviewed, they felt strongly about the benefits of social contact with others. One told us 'working alone at home for a while had made me almost lose my sanity and taken a toll on my health. I feel happier and less lonely since joining a coworking space'. We also found that some users felt motivated by others and were able to get more work done, compared with working at home. An increasing number of studies suggest that one of the most valuable aspects of coworking is the social interactions and social ties in the coworking community, instilling a sense of belonging (e.g. Mitev et al., 2019; Spinuzzi et al., 2019). Two of the interviewees commented:

It's the community that we have that makes the difference. On many occasions we have people helping each other. We have a SEO expert who is taking care of couple of other members SEO. Collaboration can mean that, if I am having a bad day, I can go for a walk with other members.

Sharing ideas and learning from others' experiences, and co-designing and co-creation are some of the activities you see here. This aspect is particularly appealing to innovative companies and entrepreneurs (Avdikos and Merkel, 2020). In this regard, the coworking space model addresses a general concern over the recent urban 
ENTREPRENEURSHIP AND SUSTAINABILITY ISSUES

ISSN 2345-0282 (online) http://jssidoi.org/jesi/

2020 Volume 8 Number 2 (December)

http://doi.org/10.9770/jesi.2020.8.2(28)

Make your research more visible, join the Twitter account of ENTREPRENEURSHIP AND SUSTAINABILITY ISSUES: @Entrepr69728810

transformation that 'public spaces and their character changed as they ceased to function as facilitators for social interaction and were reserved for merely utilitarian purposes' (Mandeli, 2019, p. 2). Our findings suggest that coworking spaces can address both social-cultural needs and economic needs of the public and demonstrate a new way to serve multiple stakeholders of smart cities.

\section{Flexibility and proximity}

We found that among the users interviewed, there were two local workers who were sent by their employers to work in coworking spaces. For them, coworking spaces were a place for fresh and innovative ideas in a nonconventional entrepreneurial' environment and provided them with the flexibility in working hours with 24/7 access and proximity to home and transportation. These participants were generally happy with this workplace arrangement and appreciated the flexibility given by their companies. This finding supports the view that flexibility helps attract and retain best talents for companies (Smith et al, 2019).

\section{Cost}

Some-cost-related reasons for coworking were cited in our interviews. For example, the lower costs compared with renting an office was one of the main reasons cited by young entrepreneurs and start-ups who had little disposable income or resources. The low-cost facilities and services provided by coworking spaces also helped start-ups to get to market quicker without the hassle of office management issues and overheads according to some our interviewees. One of the users commented that the flexible leasing terms (i.e. casual rate, weekly, monthly and yearly) of coworking spaces compared with 5-10 years' lease in rental markets helped reduce capital costs.

\section{Key challenges for providers}

We found that many of the coworking spaces we studied were facing serious issues and challenges. We identified and discussed three mostly cited issues raised by the providers interviewed (see Appendix for detail).

\section{Cost}

Six out of ten space providers whom we interviewed expressed their concerns about future funding. Some of the providers indicated that they would have to close their coworking spaces when their funding dried up and if they could not find further funding. We posit that this issue may relate to the current business models of most coworking spaces. We found that most of coworking spaces we studied were not-for-profits entities. The majority of the coworking spaces except for those owned by city councils and public educational institutions, relied primarily on membership fees and corporate sponsorship through up-selling and cross-selling other services to their users as well as organizing events, trying to reach a breakeven point. Lack of support from some city councils was cited as a key issue in particular in terms of funding. 
ENTREPRENEURSHIP AND SUSTAINABILITY ISSUES

ISSN 2345-0282 (online) http://jssidoi.org/jesi/

2020 Volume 8 Number 2 (December)

http://doi.org/10.9770/jesi.2020.8.2(28)

Make your research more visible, join the Twitter account of ENTREPRENEURSHIP AND SUSTAINABILITY ISSUES: @ Entrepr69728810

Space

Space for in coworking can be limited due to the high demand from users. Those (5 out of ten) who wanted to expand or move their coworking spaces were struggling to find affordable stock at the locations in or close to business centres and/or innovation hubs. It was reported that in Australia, coworking spaces accounted for about $5 \%$ of current city office stock and could rise to $30 \%$ by 2030 according to the current annual growth rate of $19 \%$ (Cheung, 2018). The upward trend of demand for coworking spaces could be an opportunity for advocates of smart city planning and governance to think strategically about the location, infrastructure and design of coworking spaces.

\section{Support}

Our participants were somewhat polarized in their views about the role, attitude and actions of smart city councils and urban planners with respect to coworking spaces. We found that some founders of coworking spaces were given substantial attention by their city councils. Others complained that they were rarely engaged in their city's planning process and that urban planners generally did not identify or recognize the opportunities that coworking spaces presented as a new way people can use buildings in smart cities.

\section{User retention}

Other challenges related to coworking that we found in our interviews included those associated with attracting and retaining users since most of tended to move to larger coworking spaces once they developed. The fluidity of freelance working schedules and providing parking spaces to users and their guests also made it hard for providers to meet the needs of their users and thereby retain them.

\section{Key challenges for users}

\section{Culture fit}

From the users' perspective, a vibrant community culture (e.g. shared norms, languages, and values among members) of the coworking spaces came as one of the most important issues and challenges. One of the interviews put it this way:

You get a culture, serendipity, community, and even with coworking in general, it's not about the facilities, it's all about the people, you want people who are of that same philosophy of sharing and helping each other.

\section{Distraction}

Other commonly cited issues were unwanted distraction or interruption and lack of privacy in the coworking spaces. Phone calls and side conversations were the main source of such distraction. To deal with these issues, some coworking spaces developed a code of conduct and etiquette. Some members resorted to noise cancelling headphones. Superior office facilities including size of rooms and numbers of desks as well as speed of Wifi and Internet were some of the reasons that prompted people to move from one coworking space to another. A few of the users we interviewed cited the cost of membership as a main deterrent to their use of coworking spaces. 


\section{ENTREPRENEURSHIP AND SUSTAINABILITY ISSUES}

ISSN 2345-0282 (online) http://jssidoi.org/jesi/

2020 Volume 8 Number 2 (December)

http://doi.org/10.9770/jesi.2020.8.2(28)

Make your research more visible, join the Twitter account of ENTREPRENEURSHIP AND SUSTAINABILITY ISSUES: @Entrepr69728810

\section{Discussion and Implications}

This study has examined the motivations and challenges of coworking space from both providers and user perspectives. The discrepancies and similarities identified from this study have implications for researchers and practitioners in in a range of relevant fields. First, the coworking space concept and model resonates well with the concept of smart city 2.0 which emphasizes people-centric innovations and collaborative participation (Trencher, 2019). Many researchers and practitioners favour a human-centred discourse in smart city strategy and advocate for citizen and community engagement (e.g. Carrasco-Sáez et al. 2017). Our findings show that coworking spaces contribute to collaboration, openness, and community engagement, which incidentally are the key elements of smart cities 2.0 (Trencher, 2019). From urban space and environmental perspectives, coworking spaces are likely to contribute to urban mobility and sustainability. This is another crucial component of smart cities (Annunziato and Maestosi, 2018). This is because coworking spaces located in urban community areas allow people to work closer to home and reduce average commuting time and rates of carbon emission.

Second, this study addresses an important emerging scenario in today's workforce as it becomes more fluid and mobile and takes advantage of the rapid development of digital technologies. Many jobs created in the sharing economy allow workers to decide on when, where and with whom they work with. It is estimated that the majority of U.S. workers will be freelancing by 2027 (Pofeldt, 2017). In Australia, less than half of Australians are working in a permanent full-time role in 2018 and the upward trend is growing (Jericho, 2018). Casualization in the workforce has become a notable trend, which leads to a nomadic and precarious worklife (Gandini, 2015). On the other hand, the increasing demands by workers for flexibility in terms of hours with less commuting time and more work-life balance (Erden Bayazit and Bayazit, 2019) are echoed in our findings. Research suggests that coworking spaces have become a critical urban practice because these spaces provide the support to the rising number of freelancers to cope with the informality, uncertainty and risks associated with independent work (Merkel, 2019). The implication for urban planning would be the creation of more coworking spaces and reconfiguration of some of the exiting urban spaces to meet this demand. The study suggests that these trends are likely to increase the demand for coworking spaces.

Third, the findings of this study highlight the importance of social capital generated through social interaction in coworking spaces as a platform for open innovation and collaboration. From a social capital perspective, social relations, norms and identities enable actors, whether individuals, groups or even organisations, to coordinate actions in order to achieve desired outcomes (Nahapiet and Ghoshal, 1998; Tsai and Ghoshal, 1998). Relationships form an important source of social capital providing benefits of access to information, knowledge and resources (Suseno et al. 2018). Some of the outcomes of the coworking spaces studied are a clear indication of the social capital derived from relationships and exchanges in the form of capacity building, social competency and networks (see Appendix for more detail). The study of coworking spaces from a social capital perspective would be a valuable addition to smart city ecosystem research.

Fourth, from an urban economic perspective, this study shows that coworking spaces provide a collaborative environment and often a breeding ground for entrepreneurship, where entrepreneurs and microbusinesses explore and share new production opportunities often in non-hierarchical situations (Gandini, 2015). The findings indicate that coworking spaces become start-up communities driving innovation and entrepreneurship in smart cities. Entrepreneurship was one of the most salient themes in the coworking spaces as shown in our findings. With the rapid diffusion and advances of digital technologies, digital entrepreneurship becomes increasingly a driving force for the urban economy and an imperative part of smart city ecosystems. These findings will inform 


\section{ENTREPRENEURSHIP AND SUSTAINABILITY ISSUES}

ISSN 2345-0282 (online) http://jssidoi.org/jesi/

2020 Volume 8 Number 2 (December)

http://doi.org/10.9770/jesi.2020.8.2(28)

Make your research more visible, join the Twitter account of ENTREPRENEURSHIP AND SUSTAINABILITY ISSUES: @Entrepr69728810

urban policy makers and help them better understand and tap into this source of civic entrepreneurship derived from coworking spaces.

Fifth, from a public space perspective, the findings of this study provide insight into how public spaces can be optimally used for coworking practice. Studies suggest that high quality public spaces are likely to offer economic, social and environmental benefits to their localities and communities (e.g. Carmona, 2019). The centrality of public spaces can also bring psycho-social benefits. Given the multiplicity of public spaces whether formal or informal, coworking spaces have demonstrated their value as social public spaces that encourage social engagement and diversity and contribute to the urban social fabric. This is consistent with previous studies indicating accessibility, activity, comfort, liveliness and sociability are the common benefits of public spaces (Heffernan et al., 2014; Mehaffy et al., 2019). The coworking spaces can be used as a new form of public space and a workplace to achieve these benefits. This implies that smart city planning needs to consider innovative use of high street spaces and the role of formal or informal spaces as part of a portfolio of locations where people can work and interact.

\section{Contributions, limitations and future study}

This study contributes to the extant literature and practices mainly in three ways. First, it contributes to the current understanding and research of coworking spaces and their role in developing social and cultural fabrics as well as growing entrepreneurship in smart cities. The insightful findings of this study highlight the benefits generated from the coworking spaces studied and the issues and challenges they were facing. In this regard, the study will help both providers and users of coworking spaces in running and using coworking spaces in the future. Second, the study enriches smart city literature by investigating what and how coworking spaces can do in the smart city ecosystems. This novel lens sheds light on how to conceptualize smart cities, which are more about community and citizen centric than smart technologies. Third, the study and the findings inform urban policy makers and help better understand and tap into the source of civic entrepreneurship derived from coworking spaces which could become a solid base to build digital entrepreneurship for sustainable, liveable and competitive cities (Cetindamar et al., 2020).

However, like all the studies, our research has its limitations. First, from a methodological perspective, our qualitative approach does not allow the quantitative measurement of the specific impacts or effects of coworking spaces on smart city ecosystems and urban economy and city life. However, our findings provide an in-depth insight into how coworking spaces are likely to generate, both directly and indirectly, economic and sociocultural impacts on smart cities and urban planning as well as contribute to smart city ecosystems. Future research in the form of quantitative studies could investigate the relationships between the density of coworking spaces and smart city maturity in terms of innovation, citizens' participation as well as the moderating effect of the socioeconomic characteristics of the cities in which coworking spaces operate.

Second, our study only provided a broad picture of motivations and challenges of coworking space, social relations and cultural aspect of coworking spaces should be explored at a much deeper level, which goes far beyond informal social learning (Bilandzic and Foth, 2013). For example, our findings suggest that coworking spaces help mitigate the mental and health issues of remote workers. Questions remain about the processes through which the social relations develop in coworking spaces and the role they play in not only enhancing economic performance but also fostering entrepreneurial capability building and enhancing members' mental well-being. Recent empirical research (e.g. King. 2017; Robelski et al. 2019) found that working in a coworking 
ENTREPRENEURSHIP AND SUSTAINABILITY ISSUES

ISSN 2345-0282 (online) http://jssidoi.org/jesi/

2020 Volume 8 Number 2 (December)

http://doi.org/10.9770/jesi.2020.8.2(28)

Make your research more visible, join the Twitter account of ENTREPRENEURSHIP AND SUSTAINABILITY ISSUES: @Entrepr69728810

space had a positive effect on mental health and reduced the loneliness and depression caused by the isolation of working from home. More research is needed in this regard.

Third, the relationship between smart cities and (digital) entrepreneurship have attracted some research interest recently (e.g. Sarma and Sunny, 2017; Kraus et al. 2019). The majority of the founders and users of the coworking spaces in the current study were entrepreneurs. Our interviews suggested that coworking spaces were a fertile ground for growing entrepreneurship. But given the limited space of our paper, we were not able to delve into the relationship further. Future research could investigate how the socio-technical network among entrepreneurs in the coworking spaces is likely to play a key role in smart cities.

Finally, at the time of submitting this paper, the global coronavirus pandemic has reached the stage where many of the providers and users interviewed in this study have had to temporarily shut down coworking spaces and resume working at home. What this study suggests is that this shock should not be allowed to result in more than a temporary pause to an important and dynamic aspect of the socio-economic systems surrounding smart cities. We posit that post-pandemic studies need to be conducted about the factors influencing the speed and scope of reconstruction of coworking spaces and the lessons learned about protecting and nurturing this vital aspect of the economic and socio-cultural fabric.

\section{Concluding remarks}

This paper studies the trend of coworking spaces in the context of smart cities and examines its implications in an integrative way, namely, from economic, social and cultural perspectives. By doing so, the study provides a better understanding, at a strategic level, about what role coworking spaces are likely to play in smart cities and smart city ecosystem. The findings of the study inform urban policymakers and urban planners with empirical insights into the trend of coworking spaces and the key issues and challenges they are facing, which may lead to better engagement with the trend.

Appendix - A snapshot of data display from interviews ( $\mathbf{N = 3 4 )}$

\begin{tabular}{|c|c|c|c|}
\hline $\begin{array}{l}\text { Main } \\
\text { questions }\end{array}$ & $\begin{array}{l}\text { Provider/ } \\
\text { User* }\end{array}$ & $\begin{array}{l}\text { Key themes \& No. } \\
(\%) \text { responses }\end{array}$ & Examples (Quotes) \\
\hline \multirow[t]{2}{*}{$\begin{array}{l}\text { What are } \\
\text { your main } \\
\text { purposes } \\
\text { and } \\
\text { motivations } \\
\text { as a } \\
\text { provider or } \\
\text { a user of } \\
\text { coworking } \\
\text { space? }\end{array}$} & $\begin{array}{l}\text { Provider } \\
(10)\end{array}$ & $\begin{array}{l}\text { - Entrepreneurship - } \\
10(100) \\
\text { - Community } \\
\text { building - 10(100) } \\
\text { - Collaboration - } \\
10(100)\end{array}$ & $\begin{array}{l}\text { - The objective was to build an entrepreneur eco-system and seek to } \\
\text { bring } 20,000 \text { entrepreneurs by } 2021 \text { into a membership community } \\
\text { with 1,000 members. } \\
\text { - To promote and advocate for entrepreneurship, and change the } \\
\text { culture to encourage entrepreneurship } \\
\text { - To provide incubators and physical infrastructure for young } \\
\text { entrepreneurs seeking a fashion for entrepreneurship and } \\
\text { entrepreneurial competence } \\
\text { - To facilitate collaboration, bolster motivation and provide } \\
\text { concentrated support services }\end{array}$ \\
\hline & $\begin{array}{l}\text { User } \\
(24)\end{array}$ & $\begin{array}{l}\text { - Social interaction - } \\
\text { 22(92) } \\
\text { - Entrepreneurship - } \\
13(62) \\
\text { - Flexibility - 11(46) } \\
\text { - Proximity - } 11(46) \\
\text { - Services provided - } \\
10(42)\end{array}$ & $\begin{array}{l}\text { - Working alone at home for a while had made me almost lose my } \\
\text { sanity and taken a toll on my health. I feel happier and less lonely } \\
\text { since joining a coworking space. } \\
\text { - Most of my coworking space members are entrepreneurs like me, } \\
\text { from diverse background, expertise, experience and different age } \\
\text { groups. We discuss } \\
\text { ideas and how to make them work. } \\
\text { - Flexibility in working hours means a lot to me due to family }\end{array}$ \\
\hline
\end{tabular}


ENTREPRENEURSHIP AND SUSTAINABILITY ISSUES

ISSN 2345-0282 (online) http://jssidoi.org/jesi/

2020 Volume 8 Number 2 (December)

http://doi.org/10.9770/jesi.2020.8.2(28)

Make your research more visible, join the Twitter account of ENTREPRENEURSHIP AND SUSTAINABILITY ISSUES: @Entrepr69728810

\begin{tabular}{|c|c|c|c|}
\hline & & $\begin{array}{l}\text { - } \text { Costs }-8(33) \\
\text { - Lifestyle/career } \\
\text { change - 9(38) }\end{array}$ & $\begin{array}{l}\text { commitment. The } 24 / 7 \text { access to this office is what I'm after. } \\
\text { This place is half-way between home and work, not merely the } \\
\text { physical proximity but I just feel some sense of connection with the } \\
\text { place. } \\
\text { - I don't need to worry about lease, electricity bills, catering, kitchens } \\
\text { etc. and the cost is much lower than hiring an office. I can focus on } \\
\text { doing business and rest all taken care of by the coworking space. } \\
\text { - Seeking for lifestyle change, having been in the corporate world for } \\
\text { years, wanted to be a freelancer, having my own business. }\end{array}$ \\
\hline \multirow[t]{2}{*}{$\begin{array}{l}\text { How do you } \\
\text { feel about } \\
\text { the } \\
\text { outcomes? }\end{array}$} & $\begin{array}{l}\text { Provider } \\
(10)\end{array}$ & $\begin{array}{l}\text { - } \text { Collaboration/com } \\
\text { munity - } 10(100) \\
\text { - New start-ups - } \\
10(100) \\
\text { - business skills - } \\
7(70) \\
\text { - Social competency } \\
-3(30)\end{array}$ & $\begin{array}{l}\text { - At our level, it is more about playing a community role than an } \\
\text { actual money-making business, it is more about providing these } \\
\text { start-ups with what they need and hopefully see them outgrow the } \\
\text { space like a few did. } \\
\text { After nearly three years' operation, our coworking spaces have } \\
\text { helped } 11 \text { of our members set up their own businesses and } 6 \text { of them } \\
\text { have broken even and } 1 \text { of them is very successful. We are very } \\
\text { pleased with the results so far. } \\
\text { There have been } 4 \text { VR (virtual reality) start-ups that were originated } \\
\text { from this coworking space. } \\
\text { Intelligent students are often socially and commercially naïve. After } \\
12 \text { months working in the coworking space, they have improved } \\
\text { social skills and are better leaders and managers. }\end{array}$ \\
\hline & $\begin{array}{l}\text { User } \\
(24)\end{array}$ & $\begin{array}{l}\text { - Sense of } \\
\text { community - } \\
18(75) \\
\text { - Networking } \\
\text { building - 16(67) } \\
\text { - Capacity building - } \\
8(33)\end{array}$ & $\begin{array}{l}\text { - It's the community that we have makes the difference. On many } \\
\text { occasions we have people helping each other. We have a SEO expert } \\
\text { who is taking care of couple of other members SEO. Collaboration, } \\
\text { if I am having a bad day I can go for a walk with other members. } \\
\text { - Coworking spaces break the isolation and link you with stimulating } \\
\text { interesting bright people with face-to-face contacts. } \\
\text { Coworking and mentors here help shape and refine my business } \\
\text { model; this sustains me in the cash burn and long lead times and my } \\
\text { capability development. }\end{array}$ \\
\hline \multirow[t]{2}{*}{$\begin{array}{l}\text { What are } \\
\text { the major } \\
\text { issues and } \\
\text { challenges } \\
\text { you have? }\end{array}$} & $\begin{array}{l}\text { Provider } \\
(10)\end{array}$ & $\begin{array}{l}\text { - Lack of funding - } \\
6(60) \\
\text { - Shortage of right } \\
\text { stock }-5(50) \\
\text { - Lack of support - } \\
\text { 5(50) }\end{array}$ & $\begin{array}{l}\text { - We had council's start-up fund to open the coworking space } 3 \text { years } \\
\text { ago, but they are not going to fund us again. We may have to close } \\
\text { the door soon if we can't get the support. } \\
\text { I've been planning to expand given the demand but struggling to } \\
\text { find the right stock because of location, rental price and space and } \\
\text { time flexibility. } \\
\text { I would like to see more support for coworking spaces as it is a } \\
\text { significant investment for local community and small businesses. }\end{array}$ \\
\hline & $\begin{array}{l}\text { User } \\
(24)\end{array}$ & $\begin{array}{l}\text { - } \text { Cultural fit - 13(54) } \\
\text { - } \text { Distraction - 9(38) }\end{array}$ & $\begin{array}{l}\text { - You get a culture, serendipity, community, and even with coworking } \\
\text { in general, it's not about the facilities, it's all about the people, you } \\
\text { want people who are of that same philosophy of sharing and helping } \\
\text { each other. } \\
\text { Some people ignore the presence of others when receiving calls, } \\
\text { talked quite loudly, sometimes I was forced to wear noise-cancelling } \\
\text { headphone just to be able to get work done. . }\end{array}$ \\
\hline
\end{tabular}

*Note: We interviewed a total of 10 providers and 24 users of coworking spaces. 
ENTREPRENEURSHIP AND SUSTAINABILITY ISSUES

ISSN 2345-0282 (online) http://jssidoi.org/jesi/

2020 Volume 8 Number 2 (December)

http://doi.org/10.9770/jesi.2020.8.2(28)

Make your research more visible, join the Twitter account of ENTREPRENEURSHIP AND SUSTAINABILITY ISSUES: @Entrepr69728810

\section{References}

Albino, V., Berardi, U., \& Dangelico, R. M. (2015). Smart cities: Definitions, dimensions, performance, and initiatives. Journal of urban technology, 22(1), 3-21. http://dx.doi.org/10.1080/10630732.2014.942092

Amador, C. (2018). Coworking is the new normal, and these stats prove it. Accessed online at https://allwork.space/2018/03/coworking-isthe-new-normal-and-these-stats-prove-itt/ .

Angelidou, M. (2015). Smart cities: A conjuncture of four forces. Cities, 47, 95-106. http://dx.doi.org/10.1016/j.cities.2015.05.004

Appio, F. P., Lima, M., \& Paroutis, S. (2019). Understanding Smart Cities: Innovation ecosystems, technological advancements, and societal challenges. Technological Forecasting and Social Change, 142, 1-14. http://dx.doi.org/10.1016/j.techfore.2018.12.018

Avdikos, V., \& Merkel, J. (2020). Supporting open, shared and collaborative workspaces and hubs: recent transformations and policy implications. Urban Research \& Practice, 1-10. http://dx.doi.org/10.1080/17535069.2019.1674501

Bilandzic, M., \& Foth, M. (2013). Libraries as coworking spaces: Understanding user motivations and perceived barriers to social learning. Library High Technology, 31(2), 254-273. http://dx.doi.org/10.1108/07378831311329040

Boschma, R. (2005). Proximity and innovation: a critical assessment. Regional studies, 39(1), 61-74. http://dx.doi.org/10.1080/0034340052000320887

Botsman, R., \& Rogers, R. (2011). What's mine is yours. NY: Collins, New York.

Bounchen, R. B., Laudien, S. M., Fredrich, V., \& Görmar, L. (2018). Coopetition in coworking-spaces: value creation and appropriation tensions in an entrepreneurial space. Review of Managerial Science, 12(2), 385-410. http://dx.doi.org/10.1007/s11846-017-0267-7

Bueno, S., Rodríguez-Baltanás, G., \& Gallego, M. D. (2018). Coworking spaces: a new way of achieving productivity. Journal of Facilities Management. https://doi.org/10.1108/JFM-01-2018-0006

Carmona, M. (2019). Principles for public space design, planning to do better. Urban

Design International, 24, 47-59. http://dx.doi.org/10.1057/s41289-018-0070-3

Carr, S., Francis, M., Rivlin, L. G. and Stone, A. M. (1992). Public Space. Cambridge: Cambridge University Press.

Carrasco-Sáez, J. L., Careaga Butter, M., \& Badilla-Quintana, M. G. (2017). The new pyramid of needs for the digital citizen: a transition towards smart human cities. Sustainability, 9(12), 2258. http://dx.doi.org/10.3390/su9122258

Cetindamar D., Lammers T., Sick N. (2020) Understanding the Relationship Between Smart Cities and Entrepreneurial Ecosystems: The Case of Sydney. In: Biloria N. (eds) Data-driven Multivalence in the Built Environment. S.M.A.R.T. Environments. Springer, Cham. https://doi.org/10.1007/978-3-030-12180-8_15

Cheung, A. (2018). Coworking office space in Australia to triple by 2030, report finds. Accessed on 11 September 2018 online at: https://www.commercialrealestate.com.au/news/coworking-office-space-in-australia-to-triple-by-2030-report-finds/

Costamagna, F., Lind, R., \& Stjernström, O. (2019). Livability of Urban Public Spaces in Northern Swedish Cities: The Case of Umeå. Planning Practice \& Research, 34(2), 131-148. http://dx.doi.org/10.1080/02697459.2018.1548215

Erden Bayazit, Z., and Bayazit, M. (2019). How do flexible work arrangements alleviate work-family-conflict? The roles of flexibility ideals and family-supportive cultures. The International Journal of Human Resource Management, 30(3), 405-435.

http://dx.doi.org/10.1080/09585192.2017.1278615

European Commission, 2019. Digital single market and smart cities. Accessed on 10 February 2020 at https://ec.europa.eu/digital-single$\underline{\text { market/en/smart-cities }}$ 
ENTREPRENEURSHIP AND SUSTAINABILITY ISSUES

ISSN 2345-0282 (online) http://jssidoi.org/jesi/

2020 Volume 8 Number 2 (December)

http://doi.org/10.9770/jesi.2020.8.2(28)

Make your research more visible, join the Twitter account of ENTREPRENEURSHIP AND SUSTAINABILITY ISSUES: @Entrepr69728810

Gandini, A. (2015). The rise of coworking spaces: A literature review. Ephemera, 15(1), 1-13. Accessed on 4 October 2017 at http://www.ephemerajournal.org/contribution/rise-coworking-spaces-literature-review

Gandini, A., \& Cossu, A. (2019). The third wave of coworking: 'Neo-corporate 'model versus 'resilient' practice. European Journal of Cultural Studies, http://dx.doi.org/10.1177/1367549419886060

Garrett, L. E., Spreitzer, G. M., \& Bacevice, P. A. (2017). Co-constructing a sense of community at work: The emergence of community in coworking spaces. Organization Studies, 38(6), 821-842. https://doi.org/10.1177/0170840616685354

Heffernan, E., Heffernan, T., \& Pan, W. (2014). The relationship between the quality of active frontages and public perceptions of public spaces. Urban Design International, 19(1), 92-102. http://dx.doi.org/10.1057/udi.2013.16

Jericho, G. 2018. We should be concerned about the casualisation of full-time work. The Guardian. Accessed on 13 th June 2018 at https://www.theguardian.com/business/grogonomics/2018/jan/16/we-should-be-concerned-about-the-casualisation-of-full-time-work

Kraus, S., Palmer, C., Kailer, N., Kallinger, F. L., \& Spitzer, J. (2019). Digital entrepreneurship. International Journal of Entrepreneurial Behavior \& Research. http://dx.doi.org/10.1108/IJEBR-06-2018-0425

King S. 2017. Coworking is not about workspace - It's about feeling less lonely. Harvard Business Review. Accessed on 20 June 2018 at https://hbr.org/2017/12/coworking-is-not-about-workspace-its-about-feeling-less-lonely.

Krueger, A. (2019) When libraries are also tourist draws. The Business Times (August 15th 2019). Accessed at https://www.businesstimes.com.sg/life-culture/when-libraries-are-also-tourist-draws

Kummitha, R. K. R., \& Crutzen, N. (2017). How do we understand smart cities? An evolutionary perspective. Cities, 67, 43-52. http://dx.doi.org/10.1016/j.cities.2017.04.010

Letaifa, S. B. (2015). How to strategize smart cities: Revealing the SMART model. Journal of Business Research, 68(7), 1414-1419. http://dx.doi.org/10.1016/j.jbusres.2015.01.024

Mandeli, K. (2019). Public space and the challenge of urban transformation in cities of emerging economies: Jeddah case study. Cities, 95, 102409. http://dx.doi.org/10.1016/j.cities.2019.102409

Marek, L., Campbell, M., \& Bui, L. (2017). Shaking for innovation: The (re) building of a (smart) city in a post disaster environment. Cities, 63, 41-50. http://dx.doi.org/10.1016/j.cities.2016.12.013

Mariotti, I., Pacchi, C., \& Di Vita, S. (2017). Co-working spaces in Milan: Location patterns and urban effects. Journal of Urban Technology, 24(3), 47-66. http://dx.doi.org/10.1080/10630732.2017.1311556

Marvin, S., Luque-Ayala, A., \& McFarlane, C. (Eds.). (2015). Smart urbanism: Utopian vision or false dawn? Routledge.

Meijer, A., \& Bolívar, M. P. R. (2016). Governing the smart city: a review of the literature on smart urban governance. International Review of Administrative Sciences, 82(2), 392-408. http://dx.doi.org/10.1177/0020852314564308

Mehaffy, M. W., Elmlund, P., \& Farrell, K. (2019). Implementing the new urban agenda: The central role of public space. Urban Design International, 24(1), 4-6. http://dx.doi.org/10.1057/s41289-019-00091-9

Merkel, J. (2019). 'Freelance isn't free.' Co-working as a critical urban practice to cope with informality in creative labour markets. Urban Studies, 56(3), 526-547. http://dx.doi.org/10.1177/0042098018782374

Minichiello, V., Aroni, R., \& Minichiello, V. (1990). In-depth interviewing: Researching people. Longman Cheshire.

Miles, M. B., Huberman, A. M., Huberman, M. A., \& Huberman, M. (1994). Qualitative data analysis: An expanded sourcebook. Sage. https://books.google.co.uk/books?id=U4lU_-wJ5QEC\&printsec $=$ frontcover\&source=gbs_ge_summary_r\&cad=0\#v=onepage \&q\&f=false 


\section{ENTREPRENEURSHIP AND SUSTAINABILITY ISSUES}

ISSN 2345-0282 (online) http://jssidoi.org/jesi/

2020 Volume 8 Number 2 (December)

http://doi.org/10.9770/jesi.2020.8.2(28)

Make your research more visible, join the Twitter account of ENTREPRENEURSHIP AND SUSTAINABILITY ISSUES: @Entrepr69728810

Mitev, N., De Vaujany, F. X., Laniray, P., Bohas, A., \& Fabbri, J. (2019). Coworking spaces, collaborative practices and entrepreneurship. In Collaboration in the digital age (pp. 15-43). Springer, Cham. https://www.researchgate.net/publication/326155870_Coworking_spaces_collaborative_practices_and_entrepreneurship

Mora, L., Deakin, M., \& Reid, A. (2019). Strategic principles for smart city development: A multiple case study analysis of European best practices. Technological Forecasting and Social Change, 142, 70-97. http://dx.doi.org/10.1016/j.techfore.2018.07.035

Moriset B (2014) Building new places of the creative economy: the rise of coworking spaces. In: Paper presented at the 2nd Geography of Innovation Conference, Utrecht University, Utrecht https://halshs.archives-ouvertes.fr/halshs-00914075/document

Nahapiet, J., \& Ghoshal, S. (1998). Social capital, intellectual capital, and the organizational advantage. Academy of Management Review, 23(2), 242-266. http://dx.doi.org/10.5465/amr.1998.533225

Nathan, M. (2017). The fast growth of coworking spaces in London. LSE Business Review. https://blogs.1se.ac.uk/businessreview/2017/10/11/the-fast-growth-of-co-working-spaces-in-london/

Ojo, A., Dzhusupova, Z., \& Curry, E. (2015). Exploring the Nature of the Smart Cities Research Landscape. In R. Gil-Garcia, T. A. Pardo, \& T. Nam (Eds.), Smarter as the New Urban Agenda: A Comprehensive View of the 21st Century City. Springer. https://www.researchgate.net/publication/280625329 Exploring the Nature of the Smart Cities Research Landscape

Office Hub (2018). The Australian coworking market report - 2017/2018. Accessed online at https://www.office-hub.com.au/wpcontent/uploads/2018/09/Office-Hub-The-Australian-Coworking-Market-Report-2017-18-LR.pdf

Pofeldt, E. 2017. Are We Ready For A Workforce That is 50\% Freelance? Accessed on 3rd May at 2018 https://www.forbes.com/sites/elainepofeldt/2017/10/17/are-we-ready-for-a-workforce-that-is-50-freelance/\#532a9b893f82

Ravazzoli, E., \& Torricelli, G. P. (2017). Urban mobility and public space. A challenge for the sustainable liveable city of the future. The Journal of Public Space, 2(2), 37-50. http://dx.doi.org/10.5204/jps.v2i2.91

Robelski, S., Keller, H., Harth, V., \& Mache, S. (2019). Coworking Spaces: The Better Home Office? A Psychosocial and Health-Related Perspective on an Emerging Work Environment. International Journal of Environmental Research and Public Health, 16(13), 2379. http://dx.doi.org/10.5204/jps.v2i2.91

Sarma, S., \& Sunny, S. A. (2017). Civic entrepreneurial ecosystems: Smart city emergence in Kansas City. Business Horizons, 60(6), 843853. http://dx.doi.org/10.1016/j.bushor.2017.07.010

Sancino, A., \& Hudson, L. (2020). Leadership in, of, and for smart cities-case studies from Europe, America, and Australia. Public Management Review, 1-25. http://dx.doi.org/10.1080/14719037.2020.1718189

Smith, E. F., Gilmer, D. O., \& Stockdale, M. S. (2019). The importance of culture and support for workplace flexibility: An ecological framework for understanding flexibility support structures. Business Horizons, 62(5), 557-566.

http://dx.doi.org/10.1016/j.bushor.2019.04.002

Spinuzzi, C., Bodrožić, Z., Scaratti, G., \& Ivaldi, S. (2019). "Coworking Is About Community": But What Is "Community" in Coworking? Journal of Business and Technical Communication, 33(2), 112-140. http://dx.doi.org/10.1177/1050651918816357

Suseno, Y., \& Pinnington, A. H. (2018). The significance of human capital and social capital: professional-client relationships in the Asia Pacific. Asia Pacific Business Review, 24(1), 72-89. http://dx.doi.org/10.1080/13602381.2017.1281641

Tsai, W., \& Ghoshal, S. (1998). Social capital and value creation: The role of intrafirm networks. Academy of management Journal, 41(4), 464-476. http://dx.doi.org/10.5465/257085

Tompson, T. (2017). Understanding the Contextual Development of Smart City Initiatives: A Pragmatist Methodology. She Ji: The Journal of Design, Economics, and Innovation, 3(3), 210-228. http://dx.doi.org/10.1016/j.sheji.2017.11.004

Trencher, G. (2019). Towards the smart city 2.0: Empirical evidence of using smartness as a tool for tackling social challenges. Technological Forecasting and Social Change, 142, 117-128. http://dx.doi.org/10.1016/j.techfore.2018.07.033 
ENTREPRENEURSHIP AND SUSTAINABILITY ISSUES

ISSN 2345-0282 (online) http://jssidoi.org/jesi/

2020 Volume 8 Number 2 (December)

http://doi.org/10.9770/jesi.2020.8.2(28)

Make your research more visible, join the Twitter account of ENTREPRENEURSHIP AND SUSTAINABILITY ISSUES: @Entrepr69728810

UNESCO 2019. Smart cities: shaping the society of 2030. UNESCO Publishing

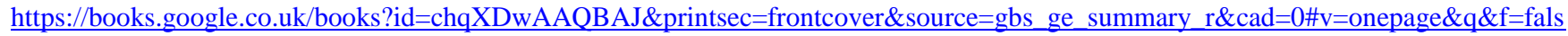
$\underline{\mathrm{e}}$

Yin, R. K. 2011. Qualitative Research From Start to Finish. New York: The Guilford Press.

Zhou, Y. (2019). A taxonomy of coworking space: Manhattan, NYC. Cornell Real Estate Review, 17(1), 58-65.

https://scholarship.sha.cornell.edu/cgi/viewcontent.cgi?article=1270\&context=crer

Fang ZHAO (PhD) is the Professor of Innovation and Strategy and Associate Dean - Research and Enterprise at Staffordshire Business School, Staffordshire University, UK. She has published over 110 research works internationally and in some of the top-tier leading journals in the study fields. Zhao's current research focuses on innovation strategy, smart cities, impact of Covid-19 on SMEs and digital transformation.

ORCID ID: 0000-0003-3718-6999

Catherine PRENTICE (PhD) is an Associate Professor of Marketing at Griffith University, Australia, and the Director of Asia Pacific Association for Gambling Studies. She has published more than 60 in Q1 or top-tier marketing and management journals within last few years. Her main research interests include service research, consumer psychology, consumer behavior, artificial intelligence, emotional intelligence, services and relationship marketing, and gambling studies.

ORCID ID: 0000-0002-7700-3889

Joseph WALLIS (PhD) is the Professor and Dean of the School of Business at the American University of Ras Al Khaimah in the United Arab Emirates. Joe's research focus is in the areas of public economics, public administration, leadership and policy reform. He has coauthored 5 books including most recently The International Handbook of Public Management Reform (Edward Elgar 2009) and Reform and Leadership in the Public Sector (Edward Elgar 2009) and has written over 90 articles in journals including Governance, World Development, Public Administration, Local Government Studies, Internet Research and Public Money and Management.

ORCID ID: 0000-0002-6584-3426

Arvind PATEL $(\mathrm{PhD})$ is the Professor and Head, School of Accounting and Finance at the University of the South Pacific. A graduate of the University of South Pacific, University of New South Wales and University of Queensland in Australia, has research interest in corporate governance, auditing, financial accounting, business finance and information systems. Publications included in top tier journals in information systems, accounting and economics. Current research interest in CEO succession and stock crash risk.

ORCID ID: 0000-0002-3223-7585

Marie-France WAXIN (PhD) is the Professor of Human Resource Management at the American University of Sharjah, in the United Arab Emirates. Her research interests and publications focus on strategic and sustainable HRM in private and public organisations. She is especially interested in talent management, global HRM, diversity management, and environmental management.

ORCID ID: 0000-0002-0660-5452

Copyright (C) 2020 by author(s) and VsI Entrepreneurship and Sustainability Center

This work is licensed under the Creative Commons Attribution International License (CC BY).

http://creativecommons.org/licenses/by/4.0/

C) (†) Open Access 